\title{
低周波数フリッカー刺激に対する視覚系の非線形応答 についての検討'
}

\author{
東北大学滝浦孝之・高橋 誠 ${ }^{2}$ 丸山欣哉
}

A study on nonlinearity of the visual system in response to the flickering stimuli in the low temporal frequency domain

Takayuki Takiura, Makoto Takahashi and Kin'ya Maruyama (Department of Psychology, Faculty of Arts and Letters, Tohoku University, Kawauchi, Aoba-ku, Sendai 980)

From different aspects than the frequency response analysis of the visual system, we investigated characteristics of the nonlinear response of the visual system to flickering stimuli in low temporal frequency domain. We measured increment threshold curves (masking functions) for $2 \mathrm{~Hz}$ flicker of rectangular and sawtooth waveforms, using six and three subjects, respectively. When the amplitude of the flicker was at a supraliminal level, the increment threshold curve had on-transients for the rapid onset larger than off-transients for the rapid offset of the flicker wave. However, around a liminal amplitude level off-transients were more prominent. This result suggests that at low temporal frequencies $(2 \mathrm{~Hz})$ the temporal contrast sensitivity may be determined mainly by the 'off-responses' in the visual system. Moreover, we found the similar changes of increment threshold curves to the flicker stimuli for a single rectangular stimulus, which means that the results as above mentioned are not specific to the periodical stimuli.

Key words: nonlinear response, visual masking functions, temporal contrast sensitivity, stimulus waveforms.

de Lange（1958）は，様々な周波数の正弦波フリッ カー刺激の振幅を変化させて, ちらつきが感じられな くなる時の閾振幅を決定するという手続きにより，い わゆる時間変調感度曲線（または時間的コントラスト 感度曲線）として今日知られているグラフを求めた。 また，その分析には線形システム理論を適用して，変 調感度曲線の形状に基づき, 視覚系は順応水準が低い 場合にはローパス・フィルタ特性をもつが，順応水準 が高くなれば，ピークを $10 \mathrm{~Hz}$ 付近にもつバンドパ ス・フィル夕特性となると説明した。この結果は

1 本研究は一部, 昭和 $53 \cdot 54 \cdot 55$ 年度文部省科学研究費一般 研究 B（課題番号 345012）の助成によるものである. また, 結 果の一部はすでに日本心理学会第 40 回大会 (丸山・高橋, 1976）および第 41 回大会（丸山・高橋, 1977a) において発表 した. 本論文はこれらの結果にデータを加えて確認し, 考察を 施したものである.

2 現所属, 労動科学研究所.

(Institute for Science of Labour, Sugao, Miyamae-ku, Kawasaki, Kanagawa 216)
Kelly（1961）によって確認されることになるが，彼 はその得られた変調感度曲線を検討して, 高周波数領 域での時間的コントラスト感度は, 順応水準に依存せ ずにリニアーに決定され，一方，低周波数領域では， それは順応水準におおよそ比例し，ノン・リニアーで ある（ウェーバー・フェヒナーの法則に近似的にあて はまるようになる）と分析した。

ところで, 正弦波以外の時間波形をもつフリッカー 刺激に対しても変調感度曲線を求めることが可能であ る. de Lange（1954）は，4種類の波形の刺激に対し てこれを求め, 正弦波刺激の場合に類する結果を得た が, 装置的な理由からか, $8 \mathrm{~Hz}$ 以下の周波数領域で は台形波の場合にしか求められていない. その後 Maruyama（1976）は, 矩形波, 正弦波, 三角波, 正 負鋸歯状波の 5 種類の波形刺激を用い，この領域でも コントラスト感度を求めて, $10 \mathrm{~Hz}$ 以上の周波数領域 ではフーリエ基本波成分の閾振幅は刺激波形に関係な く一定であるが, それ以下の領域ではコントラスト感 度に波形差がみられ，フーリエ分析による解釈が困難 
になることを示した。すなわち，5 Hz 以下の低周波 数領域では, コントラスト感度が矩形波, 正鋸歯状波 の方で正弦波，三角波，負鋸歯状波より高くなり，さ らに $2 \mathrm{~Hz}$ で矩形波と正鋸歯状波に対する感度が等し くなるのである。この非常に低い周波数領域では, 急 激な立ち下がりを有する刺激に対するコントラスト感 度が，立ち上がりの急な刺激に対するそれを上回ると いう結果は, 最近のBowen, Pokorny, \& Smith (1989)，および Bowen, Pokorny, Smith，\& Fowler (1992) によっても確かめられている.

Maruyama（1976）はこの結果から，低周波数フリ ッカー刺激に対するコントラスト感度は, 主として視 覚系の off-応答により決定されるという推測を行っ た.また Bowen et al. (1992) も， on-応答，off-応答 の文脈の中で彼らの結果を解釈している.

本研究は, 以上の先行研究に基づき, 低周波数フリ ッカー刺激に対する視覚系の非線形性の問題を, 視覚 系の周波数応答分析とは異なる文脈から探ろうとする ものである。具体的には, $2 \mathrm{~Hz}$ の矩形波抒よび正負 鋸歯状波の振幅を変化させて, それらの刺激がはっき りとちらついて感じられる場合と，ちらつきがほとん ど感じられない場合（振幅閾近傍）とで, マスキング 関数がどのように異なるかを調べる。その際, Boynton (1958), Ikeda \& Boynton（1965）などによ り主張されたように，視覚マスキング法（増分閾法） は, 視覚系の on-応答と off-応答を間接的にとらえる ことが可能であるとすると, 振幅閾近傍レベルでは, 刺激の急激な立ち下がりに対するマスキング量の方 が，急激な立ち上がりに対するマスキング量より多い という結果となれば, 上述の低周波数フリッカー刺激 に対するコントラスト感度は視覚系の off-応答に基づ いて決定されるという推測が支持されると考えられ る.

\section{方法}

刺激条件 マスク刺激の時間波形は, $2 \mathrm{~Hz}$ 矩形波, $2 \mathrm{~Hz}$ 正負鋸歯状波, および $250 \mathrm{~ms}$ 単一矩形波の 4 種類。単一矩形波は, フリッカー刺激で得られた結果 が, 繰り返し刺激に特有のものであるかを検討するた めに加えたものである。これらの刺激は, “閃光列の 周波数変調法” (丸山，1973）により作成する.すな わち, ファンクション・ジェネレータからの任意の波 形電圧を VCF (voltage-controlled-frequency) 回路に 入力すると, $700 \mathrm{~Hz}$ の矩形波搬送波が入力電圧の值 に応じて周波数変調されるわけであるが, その変調波 をワン・ショットを介して $0.055 \mathrm{~ms}$ 一定幅の矩形波 パルス列に変換し,さらにそれを高圧電流にスイッチ して，グロー変調管（Sylvania Type R1131C）をパル
ス駆動する．このグロー変調管からの閃光列の周波数 はCFF 值よりはるかに高いので, 視覚上では融合し てみえ，その周波数に応じてみえの明るさも変わるの で, 結局, VCF 回路への入力波形通りの明るさ変化 が，光源の分光組成をほとんど変化させることなしに 得られることになる（但しこの方法では, 刺激と同じ 大きさの背景光を常にともなうことになるので, 暗順 応眼に刺激を提示するといった実験事態には不向きで ある)。

刺激は 2 チャンネルマックスウェル視光学系により 被験者の右眼に提示する. マスク刺激, 背景光とも直 径 $1.72^{\circ}$ のスポット光であり, その中央部に, 別のグ ロー変調管を光源とする直径 $0.86^{\circ}$, 持続時間 $1 \mathrm{~ms}$ のテスト光が同心円状に重畳して提示される. crosshair も提示されるので，被験者はその交点を注視する ことになる。フリッカーマスク刺激の平均輝度は 10 $\mathrm{cd} / \mathrm{m}^{2}$ であるが, これは網膜照度では $31.4 \mathrm{td}$ とな る.また振幅変調度は, ちらうきがはっきりと感じら れるレベルとして 0.286, ちらつきがほとんど感じら れないレベルとして，0.051 ないし 0.026 を採用した。 なお, フリッカー刺激の最大輝度を $L_{\max }$, 最小輝度 を $L_{\min }$ とすると, 振幅変調度は次の式で定義される.

振幅変調度 $=\left(L_{\max }-L_{\mathrm{min}}\right) /\left(L_{\mathrm{max}}+L_{\mathrm{min}}\right)$

矩形波単一刺激では, 背景強度を $31.4 \mathrm{td}$, マスク刺 激の強度を $15.7 \mathrm{td}$ (閾上強度レベル) と $2.4 \mathrm{td}$ (明 るさ弁別闇近傍レベル：これは各被験者の明るさ弁別 閾より約 $0.10-0.30 \log$ unit 上の強度に相当する. 但し被験者 MTでは，約 $0.48 \log$ unit 上の強度であ る）とした（被験者 TT と MTでは，これらの中間の 刺激強度でも測定を行った)。なお刺激の時間制御に は, 主として電気刺激装置（日本光電 SEN-6100, MSE-40)を用いた。

実験手続き 実験は換気をした暗室内で行われた。 15 分間の暗順応の後, 直径 $1.72^{\circ}, 31.4 \mathrm{td}$ の刺激に 5 分間順応し, 練習試行の後, 閾值測定に入る. 被験者 はオプティカル・ウェッジを回転させることによりテ スト光の強度を変化させ, 調整法によりその消失閾を 求める. $2 \mathrm{~Hz}$ フリッカーマスク刺激条件では 1 秒に 1 回, $250 \mathrm{~ms}$ 矩形波単一刺激条件では 2 秒ないし 5 秒に 1 回の割合で，マスク刺激とテスト刺激が所定の 時間関係をもって提示される，この時間関係である SOA（マスク刺激とテスト刺激との立ち上がり時間 差）の設定はランダムな順で行った。なお，SOA は， $25,50,100,150,200,225,250,275,300,350$, 400, 450, $475 \mathrm{~ms}$ の計 14 個である.

実験は同一セッション内で, 閾上強度レベルと閾近 傍レベルの 1 つの波形のマスク刺激に対する増分閾を 各 SOA につき数個ずつ測定し, それが 1 人の被験者 
につき日をかえて数セッション繰り返された。こうし て, 最終的には各 SOAにつき 6-12 個の閾值が求め られ，その平均值がマスキング関数としてプロットさ れた。他の波形のマスク刺激に対しても同様である。 また，各セッションの前後の 2 回にわたり, マスク刺 激を提示しない場合のテスト刺激の閾値 (resting threshold）も測定する。1 セッションの所要時間は約 2 時間. 被験者は 40 代半ばの KM を除いては大学生 および大学院生であり, 全員が測定前に判断基準の確 立等について十分練習を積んでいる.

\section{結果}

得られたマスキング関数をFigure 1, Figure 2, Figure 3 に示す. Figure 1 は $2 \mathrm{~Hz}$ 鋸歯状波マスク刺 激に対するマスキング関係であり，a は正鋸歯状波の 場合の 3 人の被験者の結果, $\mathrm{b}$ 㹥鋸歯状波の場合の
同じ 3 人の結果である. Figure 2 は $2 \mathrm{~Hz}$ 矩形波マス ク刺激の場合の 6 人の結果であり，これらのグラフで は, 縦軸がテスト光の閾值の相対值（各 SOA での閾 值の平均值から resting threshold の平均值を引いた 值）の対数変換值を，また，横軸がマスク刺激の明る さが変化し始める点（立ち上がり時点）を0としたテ スト刺激の時間的位置（SOA）を表している.

結果のグラフは条件ごとにほとんど同じパターンを 与えており，この種の実験においては通常期待される ように，個人差はあまりみられない。そこでマスク刺 激の立ち上がり時拉よび立ち下がり時付近でのマスキ ング関数のオーバーシュートをそれぞれ on-効果, off-効果と呼称することにすると，これら Figure 1, Figure 2 のグラフから主たる結果は次のようにまとめ られる。

(1)いずれの波形のマスク刺激の場合も，振幅変調度

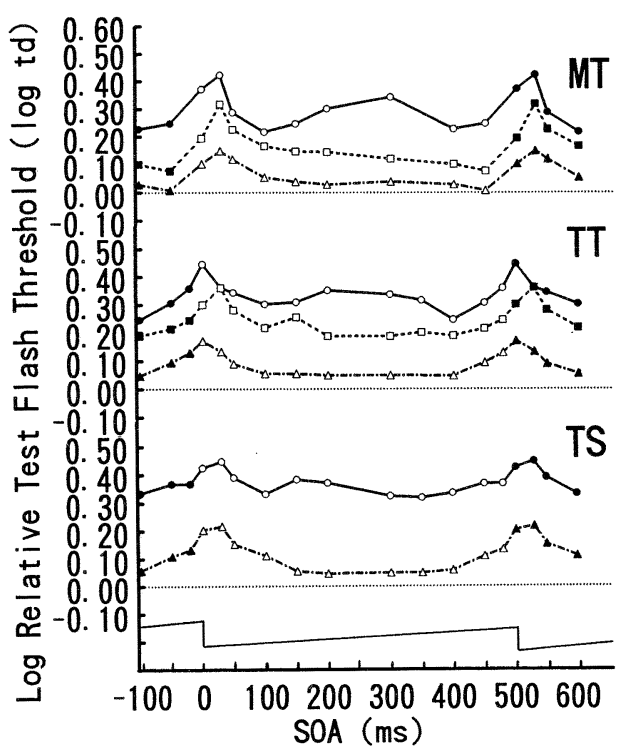

a

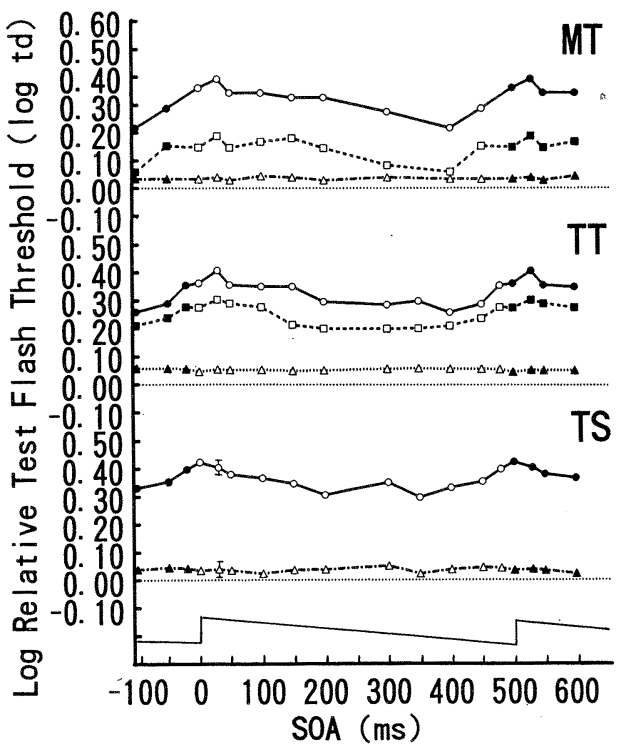

b

Figure 1. Masking functions for the $2 \mathrm{~Hz}$ positive (a) and negative (b) sawtooth flickering stimui for three subjects. Relative threshold values for the test flash are indicated along the ordinate in $\log \mathrm{td}$, and the intervals between the flickering stimulus and the test flash are shown in terms of stimulus onset asynchrony (SOA) in ms on the abscissa. Modulation ratios of the flickering stimulus are 0.286 (circles), 0.143 (squares), 0.026 (for subjects TT and TS; triangles), and 0.051 (for MT; triangles). The mean illuminance of the flickering stimulus is $31.4 \mathrm{td}$. Open symbols represent the actually obtained threshold data. Filled symbols are from extrapolation of the data. Graphs for subject MT were reproduced from Maruyama and Takahashi (1976). The standard deviations ( $S D$ s) of the data points are in almost all cases smaller than $0.30 \log$ unit, and a typical $S D( \pm 1 S D)$ is shown in TS's graph (Figure lb). 


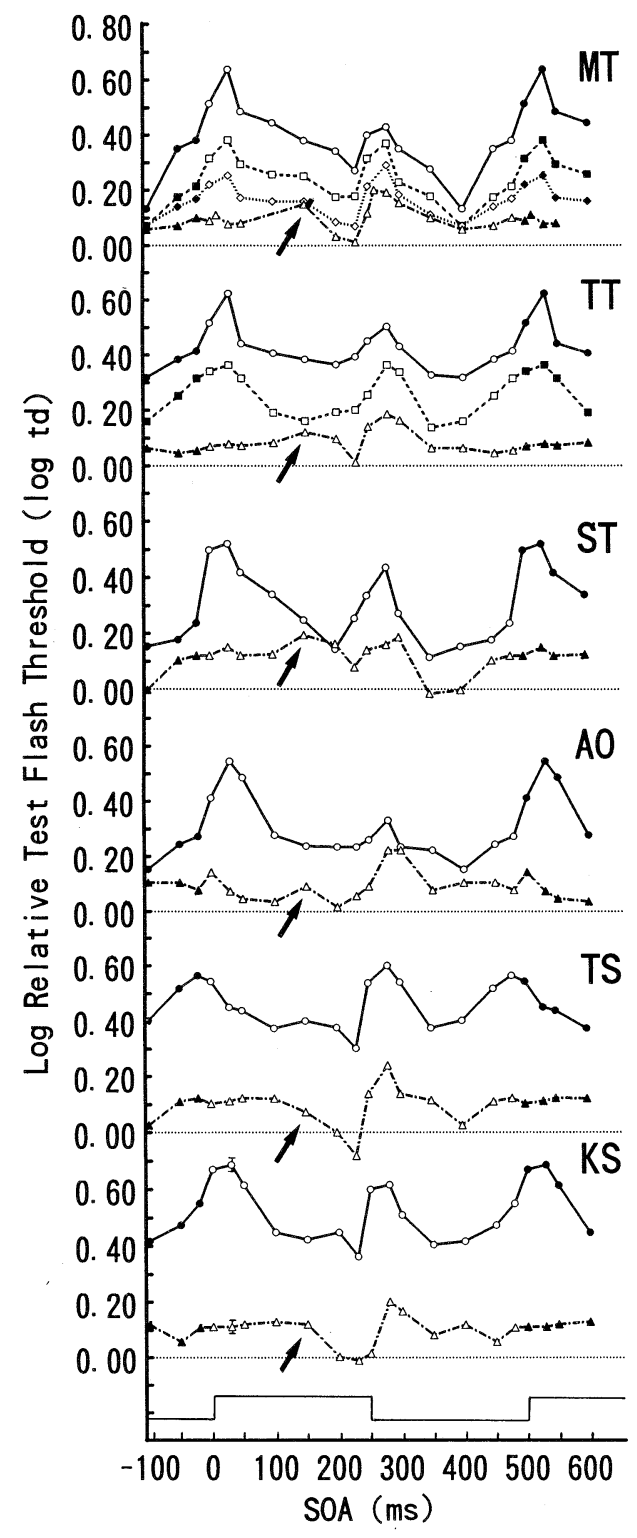

Figure 2. Masking functions for the $2 \mathrm{~Hz}$ rectangular flickering stimulus for six subjects. Modulation ratios of the flicker are 0.286 (circles), 0.143 (squares), 0.086 (diamonds), 0.026 (for subjects TT, TS, and KS; triangles), and 0.051 (for subjects MT, ST, and AO; triangeles). The mean illuminance of the flicker is 31 . 4 td. Graphs for subjects MT, ST, and AO were reproduced from Maruyama and Takahashi (1977b). A typical $S D( \pm 1 S D)$ is shown in KS's graph.
の減少にともない, on-効果は急激に減少し，振幅閾 近傍ではほとんど完全に消失してしまうが，マスク刺 激の立ち下がりが急激である場合の off-効果は, 振幅 変調度が小さくなってもその大きさを余り変えず，振 幅閾近傍でもはっきり残っている。

(2)その場合，振幅変調度の減少にともなうマスキン グ関数のピークの遅れはみられない.しかしこれは, SOA 設定の粗さに起因するものかもしれない。なお, 正鋸歯状波では $\mathrm{SOA}=200-300 \mathrm{~ms}$ 時に，また，負 鋸歯状波では $\mathrm{SOA}=300 \mathrm{~ms}$ 前後にそれぞれon-効 果, off-効果様のふくらみがマスキング関数上に現れ る場合がある。

(3)矩形波マスク刺激の場合, $\mathrm{SOA}=150 \mathrm{~ms}$ 付近に 1 つの隆起が認められる (Figure 2 中に矢印で表示). 被験者 $\mathrm{KS}$ と TSのグラフではこのふくらみがはっき りしないが, $\mathrm{SOA}=150 \mathrm{~ms}$ 付近でグラフは低下して いないので，この付近でやはり閾值を上昇させるよう な応答が生じていることを示唆している.

(4)同時にマスク刺激の立ち上がり直前では矩形波の 場合，閾値は一時急激な低下を示す. (3)と(4)はマスク 刺激の強度が振幅閾近傍の場合に，より顕著となるよ うである。

Figure 3 はフリッカー刺激ではなく, $250 \mathrm{~ms}$ 矩形 波単一刺激に対するマスキング関数であるが, $2 \mathrm{~Hz}$ 矩形波フリッカーマスク刺激の場合と同様の結果とな っていることがわかる. 但し，マスク刺激の強度が閾 近傍レベルでもフリッカーマスク刺激の場合と異な り, わずかながら on-効果が認められるが, これは刺 激提示間隔がフリッカーの場合より長くなったため に, 刺激の立ち上がりに応答するメカニズムの順応が 弱まったためと説明できよう。この場合, マスク刺激 の強度が低下すると, on-効果のピークが幾分遅れて いる. しかし off-効果の場合, ピークの遅れはみられ ない.さらに, 前述の(3), (4)の現象もまた認められ る.

\section{考察}

フリッカー刺激に対するマスキング関数を求めたの は, Boynton, Sturr, \& Ikeda (1961) に始まり，その 後 Shickman (1970) や Maruyama \& Takahashi (1977b) などの研究があるが，それらはいずれも，フリッカー 刺激が低周波数領域にあれば，マスキング関数は正弦 波状にならず，刺激の 1 周期分に対してグラフは 2 つ のピークをもつという結果を報告している。これは低 周波領域での視覚系の応答は非線形性を示すという de Lange (1958), Kelly (1961), Maruyama (1976) などの結果を支持するものであると同時に，一歩進ん で，その非線形性の原因の一部が視覚系の on-応答お 
よび off-応答に帰せられることを示唆するものであ る.しかし，これらの研究では，一般に報告されてい る視覚マスキングの場合と同様に, on-効果の方が off-効果より大きくなっている。一方，今回の結果 は, 刺激の強度をさらに下げて, 閾近傍レベルに設定 すると,これらの大小関係が逆転し, off-効果の方が 大きくなるというものであった．従ってもし Boynton (1958), Ikeda \& Boynton（1965）の言うように，視

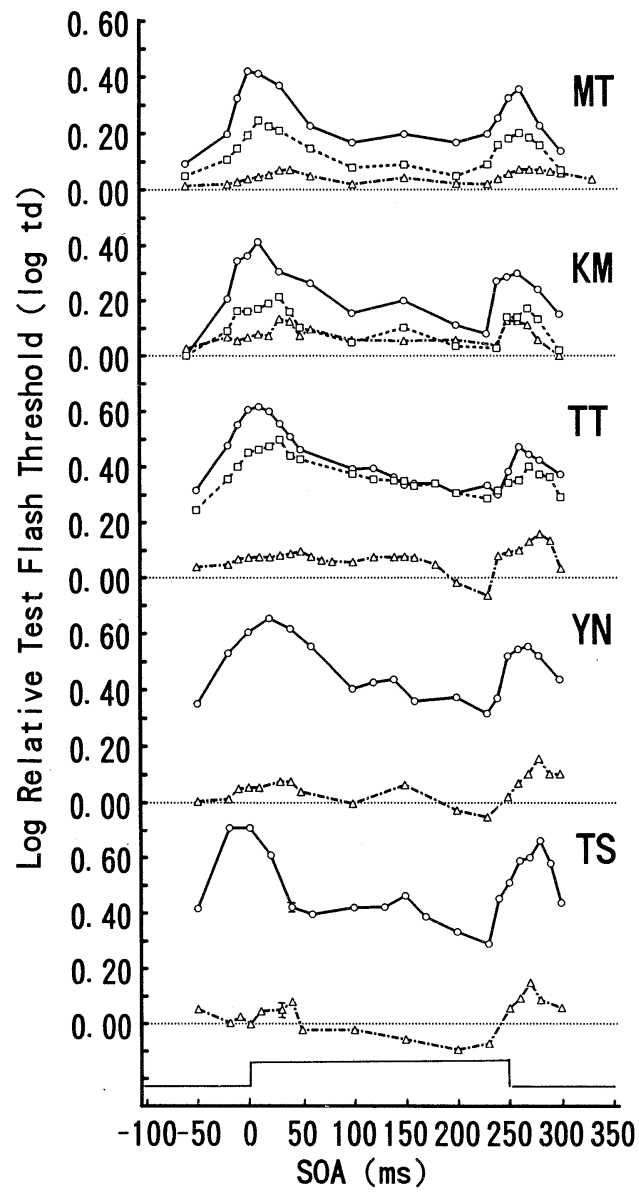

Figure 3. Masking functions for a single rectangular masking stimulus of $250 \mathrm{~ms}$ in duration for five subjects. The intensities of the masking stimulus are $15.7 \mathrm{td}$ (circles), $4.7 \mathrm{td}$ (for subjects $\mathrm{KM}$ and TT; squares), $6.3 \mathrm{td}$ (for MT; squares), and $2.4 \mathrm{td}$ (triangles). The adapting level of the eye is $31.4 \mathrm{td}$. Graphs for subjects MT and KM are reproductions from Maruyama and Takahashi (1977b). A typical $S D$ $( \pm 1 S D)$ is shown in TS's graph.
覚マスキングの手法により, 視覚系の on-応答と off応答とを, 間接的にではあるがとらえることができる とすれば,この結果は, 低周波数領域での視覚系の感 度は, 変調感度といった閾レベルでは, 主として off応答の大きさにより規定されるという Maruyama (1976）の推測に合致するものと言えよう。しかし, それを言うためにはやはり Boynton (1958), Ikeda \& Boynton（1965）の説の妥当性について考えておく必 要がある。

Kuffler（1953）がネコの網膜神経節細胞には on-中 心型のものと off-中心型のものとがあり, それぞれ拮 抗的な周辺部を有する同心円的受容野構造をしている ことを見出したのは周知のことであるが, on-メカ二 ズムと off-メカニズムは機能的にも生理的・解剖学 的にも異なっていることを示唆するような研究は多 くある (Anstis, 1967 ; Gernandt \& Granit, 1947 ; Fiorentini, Baumgartner, Magnussen, Schiller, \& Thomas, 1990 ; Helmholtz, 1867 ; Krauskopf, 1980 ; Peichl \& Wässle, 1981 ; Schiller, 1982, 1984 ; Schiller, Sandell, \& Maunsell, 1986 ; Slaughter \& Miller, 1981 ; Wässle, Peichl, \& Boycott, 1983). 特に Schiller (1982, 1984), Schiller et al. (1986), Slaughter \& Miller（1981）などは，視覚皮質以前では両メカニズ ムは独立していることを示しており, 刺激の立ち上が り，および立ち下がりに対する情報は独立して伝達さ れることを示唆している。また，今回の実験で用いら れたテスト光のような非常に短い光刺激に対しては, 視覚系は on-応答が優勢となり, off-応答はほとんど あるいは全く生じないということも電気生理学的に明 らかにされている (Baumgartner, 1955；Efron, 1973； Scheich \& Korn, 1971 ; Servière, Miceli, \& Galifret, 1977). 従ってマスキング関数に現れたピークのうち, on-効果はマスク刺激に対する on一応答とテスト刺激 に対するそれが同一径路内で干渉するために，マスク 刺激に対する on-応答の時間的経過をなぞうていると 考えることができるが，off-効果の場合は，マスク刺 激の立ち下がりに対して生じた off-応答と, テスト光 に対して生じた on-応答とが, 同一径路内で相互作用 するとは考えにくい.

しかし, Stelmach, Bourassa, \& Di Lollo (1984, 1987）が精神物理学的に示したように, 輝度変化方向 の異なる 2 刺激間には確かに相互作用が存在する。ま た, Schiller (1982) は, 視覚皮質では on-メカニズ ムと off-メカニズムとが相互作用することを生理学的 に明らかにしており, Singer \& Creutzfeldt (1970) は, ネコの LGN のレベルで，受容野の重なる，ある いは隣接する on-中心型ニューロンと off-中心型ニュ ーロンとは相互抑制することを報告している。これら 
を考えに入れると, 閾近傍の弱いごく短いテスト刺激 に対する弱い on-応答を伝達する on一メカニズムが, マスク刺激の立ち下がりによって活性化した off-メカ ニズムからの抑制をうけ, 結果的に生じた増分閾の上 昇が off-効果にほかならないという推測が可能とな る.すなわち, off-効果の反映しているものは, 正確 には視覚系の off-応答そのものに大きさというより は， off-メカニズムの on-メカニズムに対する抑制の 強さであるということになるが，それは off-応答の強 さに比例するから, 結果的には off-応答の時間的経過 を間接的に反映していると考えることができる. 生理 学的にも, 刺激強度がごく低くなると, on一応答より off-応答の方が大きくなるという知見が古くから知ら れて抢り (Hartline, 1938)，この考えに基づく解釈の 妥当性を示している。したがって Boynton (1958), Ikeda \& Boynton（1965）の説の妥当性は保証される と考えてよいであろう。

このようにみてくると, 今回の実験結果は, やはり 前述の Maruyama（1976）の主張（低周波数フリッカ 一刺激に対するコントラスト感度は，主として視覚系 の off-応答により決定される）を支持するものである といえる. 低周波数領域での視覚系の応答が非線形性 を示すことはよく知られているものの，それがどのよ うなメカニズムによるのかを精神物理学的に明らかに した研究は少ない.本研究は視覚マスキングという手 法を用い，視覚の周波数応答研究とは別な面からこの 現象を探ろうとしたものであり，この低周波数領域で は，刺激の立ち下がりに対する視覚系の応答が中心視 での閾振幅刺激に対する感受性を決定していることを 明らかにした。しかも，このことはなにも繰り返し刺 激に特有ではない. Figure 3 の結果にみられるよう に，非周期的刺激の場合にも同様に言えるのである. ということは，少なくとも眼が明順応状態にあるとき には，われわれにとって，強い光刺激はその出現が， ごく弱い光刺激ではその消失がより大きな意味をもつ ということになろう.

\section{要 約}

本研究では，de Lange（1958）の時間変調感受曲線 にみられる低周波数領域の刺激に対する視覚系の非線 形性を, 視覚系の周波数応答分析とは異なる, 視覚マ スキング（増分閾法）という手続きにより検討した. すなわち，閾上振幅と閾近傍振幅とをもつ $2 \mathrm{~Hz}$ の矩 形波および正負鋸歯状波フリッカー刺激に対するマス キング関数を求め, その振幅が関数形におよぼす影響 を調べたところ，閾上振幅では刺激の急激な立ち上が りに対する増分閾の上昇が急激な立ち下がりに対する それの程度を上回ったのに対して, 閾近傍振幅の場合
はこの大小関係が逆転した．本論中の考察をふまえれ ば，このような閾值の上昇の程度が視覚系の on-応答 と off-応答の大きさを反映していると考えられるの で,この結果は, $2 \mathrm{~Hz}$ といった超低周波数領域では, 視覚系は刺激の立ち下がりに対してより感度が高いこ とを示していると解することができる. 従って, 低周 波数領域での視覚系の非線形性の少なくとも一部は視 覚系の off-応答に起因するという推論が成り立つ.

\section{引用文献}

Anstis, S. M. 1967 Visual adaptation to gradual change of intensity. Science, 155, 710-711.

Baumgartner, G. 1955 Reaktionen einzelner Neurone im optischen Cortex der Katze nach Lichtblitzen. Pflugers Archiv für die gesamte Physiologie des Menschen und der Tiere, 261, 457-469.

Bowen, R. W., Pokorny, J., \& Smith, V.C. 1989 Sawtooth contrast sensitivity: Decrements have the edge. Vision Research, 29, 1501-1509.

Bowen, R. W., Pokorny, J., Smith, V. C., \& Fowler, M. A. 1992 Sawtooth contrast sensitivity: Effects of mean illuminance and low temporal frequencies. Vision Research, 32, 1239-1247.

Boynton, R. M. 1958 On-responses in the human visual systems as inferred from psychophysical studies of rapid-adaptation. A. M. A. Archives of Ophthalmology, 60, 800-810.

Boynton, R. M., Sturr, J. F., \& Ikeda, M. 1961 Study of flicker by increment threshold technique. Journal of the Optical Society of America, 51, 196-201.

de Lange, H. 1954 Relationship between critical flicker frequency and a set of low frequency characteristics of the eye. Journal of the Optical Society of America, 44, 380-389.

de Lange, H. 1958 Research into the dynamic nature of the human fovea $\rightarrow$ cortex systems with intermittent and modulated light. I. Attenuation characteristics with white and colored light. Journal of the Optical Society of America, 48, 777-784.

Efron, R. 1973 An invariant characteristic of perceptual systems in the time domain. In S. Kornblum (Ed.), Attention and performance $I V$. New York: Academic Press. Pp. 713-736.

Fiorentini, A., Baumgartner, G., Magnussen, S., Schiller, P. H., \& Thomas, J.P. 1990 The perception of brightness and darkness. Relations to neuronal receptive fields. In L. Spillmann \& J. S. Werner (Eds.), Visual perception: The neurophysiological foundations. New York: Academic Press. Pp. 129-161.

Gernandt, B., \& Granit, R. 1947 Single fibre analysis of inhibition and the polarity of the retinal elements. Journal of Neurophysiology, 10, 295-301. 
Hartline, H. K. 1938 The response of single optic nerve fibers of the vertebrate eye to illumination of the retina. American Journal of Physiology, 121, 400-415.

Helmholtz, H. von 1867 Handbuch der physiologischen Optik. Leibzig: Leopold Voss.

Ikeda, M., \& Boynton, R. M. 1965 Negative flashes, positive flashes, and flicker examined by increment threshold technique. Journal of the Optical Society of America, 55, 560-566.

Kelly, D. H. 1961 Visual responses to time dependent stimuli. I. Amplitude sensitivity measurements. Journal of the Optical Society of America, 51, 422-429.

Krauskopf, J. 1980 Discrimination and detection of changes in luminance. Vision Research, 20, 671-677.

Kuffler, S. W. 1953 Discharge patterns and functional organization of mammalian retina. Journal of Neurophysiology, 16, 37-68.

丸山欣哉 1973 閃光列の周波数変調法により形成さ れた刺激波形のフリッカー視 日本心理学会第 37 回大会発表論文集, 16-17.

Maruyama, K. 1976 Stimulus wave form and modulation sensitivity curve. Tohoku Psychologica Folia, 35, $122-129$.

丸山欣哉・高橋 誠 1976 フリッカー刺激の波形差 と視覚マスキング 日本心理学会第 40 回大会発表 論文集, 317-318.

丸山欣哉・高橋 誠 $1977 \mathrm{a}$ 矩形波刺激における視 覚マスキングの on-, off-効果 日本心理学会第 41 回大会発表論文集, 176-177.

Maruyama, K., \& Takahashi, M. 1977b Wave form of flickering stimulus and visual masking function. Tohoku Psychologica Folia, 36, 120-133.

Peichl, L., \& Wässle, H. 1981 Morphological identification of on- and off-centre brisk transient (Y) cells in the cat retina. With an appendix 'Neurofibrillar staining of cat retinae,' by B. B. Boycott \& L. Peichl. Proceedings of the Royal Society of London, Series B, 212, 139-156.

Scheich, H., \& Korn, A. 1971 Timing properties and temporal summation in the retina. Pflugers Archiv, 327, 16-36.

Schiller, P. H. 1982 Central connections on the retinal ON- and OFF-pathways. Nature, 297, 580583.

Schiller, P. H. 1984 The connections of the retinal $\mathrm{ON}$ - and OFF-pathways on the lateral geniculate nucleus of the monkey. Vision Research, 24, 923-932.

Schiller, P. H., Sandell, J. H., \& Maunsell, J. H. R. 1986 Functions of the ON and OFF channels of the visual system. Nature, 322, 824-825.

Servière, J., Miceli, D., \& Galifret, Y. 1977 Electrophysiological correlates of the visual perception of "instantaneous" and "durable." Vision Research, 17, 65-69.

Shickman, G. M. 1970 Visual masking by lowfrequency sinusoidally modulated light. Journal of the Optical Society of America, 60, 107-117.

Singer, W., \& Creutzfeldt, O. D. 1970 Reciprocal lateral inhibition of on- and off-center neurones in the lateral geniculate body of the cat. Experimental Brain Research, 10, 311-330.

Slaughter, M. M., \& Miller, R. F. 1981 2-Amino-4phosphonobutyric acid: A new pharmacological tool for retina research. Science, 211, 182-184.

Stelmach, L. B., Bourassa, C. M., \& Di Lollo, V. 1984 Detection of stimulus change: The hypothetical roles of visual transient responses. Perception \& Psychophysics, 35, 245-255.

Stelmach, L. B., Bourassa, C. M., \& Di Lollo, V. 1987 On and off systems in human vision. Vision Research, 27, 919-928.

Wässle, H., Peichl, L., \& Boycott, B. B. 1983 A spatial analysis of on- and off-ganglion cells in the cat retina. Vision Research, 23, 1151-1160.

- 1993. 2. 22. 受稿, 1994. 3. 5. 受理—— 